\title{
UPAYA MENINGKATKAN KEMAMPUAN PEMECAHAN MASALAH MATEMATIKA SISWA MELALUI PENERAPAN MODEL PROBLEM BASED LEARNING
}

\author{
Umi Supraptinah \\ SMP Negeri 1 Masaran Kabupaten Sragen \\ usupraptinah@gmail.com
}

\begin{abstract}
This study aims to determine: (1) How the application of Problem Based Learning $(P B L)$ model can improve mathematical problem solving skills, (2) The extent to which the application of PBL model can improve mathematical problem solving skills, and (3) improvement of mathematics learning outcomes through the application of PBL models. The research subjects were students VIIIF class at the even semester, SMPN 1 Masaran in the academic year of 2016/2017. This research was held for 3 months, starting from January to March 2017. The research is a classroom action research consisting of 2 cycles. Each cycle consist of: planning, operating, observation, and reflection. Data analysis was carried out using comparative descriptive techniques. The results of the research are: (1) PBL model can improve mathematical problem solving skills if the teacher masters and applies it well based on the steps: student orientation on problems, diagnosing problems, conducting individual or group investigations, developing and presenting the results of problem solving, and evaluation, (2) The application of PBL models can improve students' mathematical problem solving skills by $7.52 \%$ from $55.64 \%$ at the end of the first cycle to $63.16 \%$ at the end of the second cycle, (3) The application of PBL models can improve learning outcomes aspects of understanding concepts, namely the average value of students' daily replay increased by $10.86 \%$ from $73.76 \%$ at the end of the first cycle to $84.62 \%$ at the end of the second cycle and the completeness of student learning increased by $22.58 \%$ from $64.52 \%$ end of first cycle increased to $87.10 \%$ at the end of the second cycle.
\end{abstract}

Keyword: learning outcomes, problem based learning, problem solving

Abstraksi. Penelitian ini bertujuan untuk mengetahui: (1) Bagaimana penerapan model Problem Based Learning (PBL) dapat meningkatkan kemampuan pemecahan masalah matematika, (2) Sejauh mana penerapan model PBL dapat meningkatkan kemampuan pemecahan masalah matematika, dan (3) Seberapa besar model PBL dapat meningkatkan hasil belajar matematika. Subjek penelitian adalah siswa kelas VIII F Semester Genap SMP Negeri 1 Masaran tahun pelajaran 2016/2017. Penelitian ini dilaksanakan selama 3 bulan, yaitu mulai bulan Januari sampai dengan bulan Maret 2017. Jenis penelitian ini adalah penelitian tindakan kelas yang terdiri dari 2 siklus, dengan langkah-langkah setiap siklus terdiri dari: perencanaan, pelaksanaan, observasi, dan refleksi. Analisis data dilakukan dengan teknik deskriptif komparatif. Hasil penelitian yang diperoleh adalah: (1) Model PBL dapat meningkatkan kemampuan pemecahan masalah matematika jika guru menguasai dan dapat menggunakannya dengan baik sesuai langkah-langkah: orientasi siswa pada masalah, mendiagnosis masalah, melakukan penyelidikan individu atau kelompok, mengembangkan dan menyajikan hasil pemecahan masalah, serta evaluasi, (2) Penerapan model PBL dapat meningkatkan kemampuan pemecahan masalah matematika siswa sebesar 7,52\% dari 55,64\% pada akhir siklus I menjadi 63,16\% pada akhir siklus II, (3) Penerapan model PBL dapat meningkatkan hasil belajar aspek pemahaman konsep, yaitu nilai rata-rata ulangan harian siswa meningkat 10,86\% dari 73,76\% pada akhir siklus I menjadi $84.62 \%$ pada akhir siklus II dan ketuntasan belajar siswa meningkat sebesar 22,58\% dari $64,52 \%$ pada akhir siklus I meningkat menjadi $87,10 \%$ pada akhir siklus II.

Kata kunci: hasil belajar, pemecahan masalah, problem based learning 


\section{PENDAHULUAN}

Matematika memiliki peranan yang sangat penting dalam kehidupan manusia. Matematika perlu diberikan sejak dini karena peran matematika yang sangat penting bagi kehidupan sehari-hari maupun dalam perkembangan ilmu dan teknologi. Melalui mata pelajaran matematika diharapkan siswa memiliki kemampuan dan kecakapan matematika yang sangat diperlukan dalam kehidupannya kelak. Hal ini sesuai dengan pernyataan Kemdikbud (2015) yang menyebutkan bahwa, "Mata pelajaran matematika perlu diberikan kepada semua siswa mulai dari Sekolah Dasar, untuk membekali siswa dengan kemampuan berpikir logis, analitis, sistematis, kritis, inovatif, dan kreatif, serta kemampuan bekerja sama".

Salah satu tujuan mata pelajaran matematika adalah menggunakan penalaran pada sifat, melakukan manipulasi matematika baik dalam penyederhanaan, maupun menganalisa komponen yang ada dalam pemecahan masalah dalam konteks matematika maupun di luar matematika (Kemdikbud, 2015). Dengan kata lain mata pelajaran matematika bertujuan agar siswa mempunyai kemampuan pemecahan masalah. Kemampuan ini meliputi kemampuan memahami masalah, membangun model matematika, menyelesaikan model dan menafsirkan solusi yang diperoleh.

Berdasarkan pengalaman dan pengamatan penulis selama ini, di SMP Negeri 1 Masaran kemampuan pemecahan masalah memang kurang dikembangkan dalam kegiatan belajar mengajar di kelas. Apalagi untuk mata pelajaran matematika yang menurut sebagian siswa merupakan pelajaran yang sulit. Biasanya guru lebih menitikberatkan pada pemahaman konsep serta penerapannya. Soal-soal penalaran juga sudah diberikan pada siswa, tetapi biasanya berupa soal-soal penalaran sederhana, belum membiasakan untuk soal-soal yang menuntut penalaran tingkat tinggi. Begitu juga untuk soal bertipe pemecahan masalah yang menuntut pemikiran kritis serta memerlukan penalaran tingkat tinggi.

Kemampuan pemecahan masalah matematika dapat dilihat dari kemampuan siswa dalam menyelesaikan soal-soal bertipe pemecahan masalah. Biasanya berupa soal cerita yang memuat masalah tidak rutin, yaitu masalah yang tidak bisa diselesaikan langsung dengan menggunakan rumus yang ada. Siswa perlu melakukan usaha tambahan, misalnya memecah masalah menjadi beberapa masalah yang sudah dikenal, melakukan manipulasi aljabar, dan sebagainya. Oleh karena itu, soal pemecahan masalah biasanya dianggap sebagai soal yang sulit. Karena kesulitan ini, jika diberikan soal pemecahan masalah, sebagian siswa sengaja tidak menjawab dengan alasan tidak tahu apa yang harus ditulis.

Guru juga merasa kesulitan dalam menjelaskan dan membuat siswa memahami penyelesaian suatu masalah matematika. Apalagi waktu yang diperlukan untuk menyelesaikan soal pemecahan masalah relatif lebih lama sehingga kebanyakan guru malas membahasnya. Akibatnya guru jarang memberikan soal-soal pemecahan masalah. 
Sementara itu, berdasarkan kisi-kisi Ujian Nasional SMP untuk mata pelajaran matematika yang dikeluarkan oleh BSNP, dinyatakan bahwa siswa diharapkan dapat menggunakan nalar yang berkaitan dengan materi matematika. Hal ini berarti soal yang diujikan dalam Ujian Nasional mencakup soal penalaran. Oleh karena itu kemampuan pemecahan masalah yang pada intinya menggunakan penalaran dalam penyelesaian masalah matematika perlu dikembangkan dalam pembelajaran di kelas.

Materi lingkaran termasuk pada kelompok geometri yang berkaitan dengan gambar-gambar dan rumus-rumus yang banyak. Untuk konsep pengertian lingkaran atau bagian-bagian lingkaran, siswa tidak mengalami kesulitan. Tetapi ketika dihadapkan pada soal berbentuk gambar atau perhitungan yang angkaangkanya besar, siswa mulai kesulitan. Pada tahun sebelumnya yaitu tahun pelajaran 2015/2016 untuk materi lingkaran dengan KKM 75, hasil belajar siswa SMP Negeri 1 Masaran belum menggembirakan. Nilai rata-rata yang diperoleh hanya sebesar 62 atau daya serap siswa $62 \%$. Meskipun ada siswa yang meraih nilai tertinggi 100 , tetapi prosentase ketuntasan belajar hanya $57,5 \%$.

Untuk mencapai tujuan pembelajaran yang dapat meningkatkan kemahiran matematika, khususnya kemampuan pemecahan masalah, pelaksanaan pembelajaran matematika diharapkan menggunakan pendekatan, strategi, dan model pembelajaran yang memicu peserta didik agar aktif berperan dalam proses pembelajaran dan membimbing peserta didik dalam proses pengajuan masalah (problem posing) dan pemecahan masalah (problem solving). Model pembelajaran berbasis masalah atau Problem Based learning (PBL) adalah model pembelajaran yang menggunakan masalah sebagai langkah awal untuk mendapatkan pengetahuan baru. Prinsip utama PBL adalah menggunakan masalah nyata sebagai sarana bagi siswa untuk mengembangkan pengetahuan dan sekaligus mengembangkan kemampuan berpikir kritis dan kemampuan pemecahan masalah.

Berdasarkan uraian di atas, maka peneliti melakukan penelitian tindakan kelas mengenai penerapan model pembelajaran berbasis masalah atau Problem Based Learning untuk meningkatkan kemampuan pemecahan masalah matematika siswa pada materi lingkaran untuk siswa kelas VIII F SMP Negeri 1 Masaran.

Rumusan masalah dalam penelitian ini adalah :

1. Bagaimana menerapkan model Problem Based Learning dalam pembelajaran matematika agar dapat meningkatkan kemampuan masalah matematika siswa?

2. Sejauh mana penerapan model Problem Based Learning dapat meningkatkan kemampuan pemecahan masalah matematika siswa?

3. Seberapa besar penerapan model Problem Based Learning dapat meningkatkan hasil belajar matematika siswa? 
Tujuan khusus penelitian ini adalah menjawab rumusan masalah, sedang tujuan umumnya adalah memberikan gambaran pada para pendidik khususnya guru-guru matematika tentang perlunya menerapkan model pembelajaran yang bervariasi, misalnya model Problem Based Learning. Penelitian ini diharapkan bermanfaat bagi siswa untuk dapat meningkatkan hasil belajar maupun kemampuan pemecahan masalah matematika, sedangkan bagi guru merupakan sumbangan pemikiran untuk dapat meningkatkan kualitas pembelajaran matematika, kreativitas, kinerja, dan profesionalismenya

\section{Hasil Belajar Matematika}

Matematika merupakan ilmu universal yang berguna bagi kehidupan manusia dan juga mendasari perkembangan teknologi modern, serta mempunyai peran penting dalam berbagai disiplin dan memajukan daya pikir manusia (Kemdikbud, 2014). Matematika juga dinyatakan sebagai suatu ilmu pengetahuan mengenai telaah tentang pola dan hubungan, suatu pola berpikir, suatu seni, suatu bahasa yang dapat dinyatakan dengan bahasa simbol yang dapat memajukan daya pikir manusia dan membantu manusia dalam memahami masalah-masalah nyata dalam kehidupan.

Hasil dari suatu proses pembelajaran adalah hasil belajar siswa. Hasil belajar adalah kemampuan-kemampuan yang dimiliki siswa setelah ia menerima pengalaman belajar. Hasil belajar siswa pada hakikatnya adalah perubahan yang meliputi bidang kognitif, afektif dan psikomotorik yang berorientasi pada proses belajar mengajar yang dialami siswa (Sudjana, 2010). Dari pengertian ini dapat dikatakan bahwa hasil belajar merupakan gabungan antara tindak belajar siswa dan proses mengajar oleh guru. Hasil belajar siswa dapat diketahui dari hasil penilaian yang dapat berupa ulangan harian, ulangan tengah semester, maupun ulangan semester, sebagaimana pendapat berikut, "Dampak pengajaran adalah hasil yang dapat diukur seperti tertuang dalam angka ulangan, angka rapot". (Dimyati dan Mudjiono, 2009).

\section{Kemampuan Pemecahan Masalah}

Kemampuan pemecahan masalah adalah bagian dari kecakapan atau kemahiran matematika yang seharusnya dimiliki oleh siswa setelah mengikuti proses pembelajaran di kelas. Pemecahan masalah dalam matematika merupakan kemampuan yang sangat penting karena dalam proses pembelajaran, siswa dimungkinkan memperoleh pengalaman menggunakan pengetahuan serta ketrampilan yang sudah dimiliki untuk diterapkan pada pemecahan masalah nyata sebagaimana pendapat Mulyono Abdurrahman (2003) berikut:

Pemecahan masalah adalah aplikasi dan konsep ketrampilan. Dalam pemecahan masalah biasanya melibatkan beberapa kombinasi konsep dan ketrampilan dalam suatu situasi baru atau situasi yang berbeda. Sebagai contoh, pada saat siswa diminta untuk mengukur luas selembar papan, beberapa konsep dan ketrampilan ikut terlibat. Beberapa konsep yang terlibat adalah bujur sangkar, garis sejajar, dan sisi; dan beberapa ketrampilan yang terlibat adalah ketrampilan mengukur, menjumlahkan dan mengalikan. 
Kemampuan atau ketrampilan pemecahan masalah adalah kemampuan yang dikembangkan melalui pembelajaran matematika, karena melalui matematika dapat dikembangkan kompetensi seseorang dalam penalaran logis, visualisasi spasial, analisis, dan pemikiran abstrak yang nanti akan digunakan dalam kehidupan sehari-hari sebagaimana pendapat berikut:

Mathematics is an excellent vehicle for the development of a person's intellectual competence in logical reasoning, spatial visualization, analysis and abstract thought. Students develop numeracy, reasoning, thinking skills and problem solving skills throught the learning and application of mathematics. These are valued not only in science and technology but also in everyday living and in the workplace (Akinmola, 2014).

Dari beberapa pendapat di atas dapat disimpulkan bahwa kemampuan pemecahan masalah adalah kemampuan siswa yang meliputi cara berpikir maupun bernalar dalam menggunakan pengetahuan, ketrampilan maupun pengalaman yang diperoleh dari proses pembelajaran untuk menyelesaikan permasalahan matematika. Kriteria/ indikator penilaian kemampuan pemecahan masalah siswa meliputi:

1) Memahami masalah (pemahaman terhadap masalah, menterjemahkan masalah, mengorganisasi data, memilih informasi yang relevan)

2) Merencanakan strategi penyelesaian masalah, dapat berupa membuat gambar, membuat dugaan, atau berpikir dari belakang dari yang diketahui.
3) Melaksanakan strategi penyelesaian masalah.

4) Mengecek hasil penyelesaian masalah.

\section{Model Pembelajaran Berbasis Masalah (PBL)}

Menurut Wina Sanjaya (2006) Pembelajaran berbasis masalah dapat diartikan sebagai rangkaian aktivitas pembelajaran yang menekankan pada proses penyelesaian masalah yang dihadapi secara ilmiah. Menurut Wina Sanjaya (2006) terdapat 3 ciri utama dari model PBL, yaitu : a. Model PBL merupakan rangkaian aktivitas pembelajaran yang menekankan pada keaktifan siswa, artinya siswa tidak hanya mendengarkan, mencatat, menghafal materi pelajaran, akan tetapi melalui model PBL siswa diharapkan aktif berpikir, berkomunikasi, mencari dan mengolah data, dan akhirnya menyimpulkan, b. Aktivitas pembelajaran diarahkan untuk menyelesaikan masalah, dan c. Pemecahan masalah dilakukan dengan menggunakan pendekatan berpikir secara ilmiah.

Langkah - langkah pembelajaran dengan model PBL Menurut Johnson \& Johnson dalam Wina Sanjaya (2006) meliputi mendefinisikan masalah, mendiagnosis masalah, merumuskan alternatif strategi, menentukan dan menerapkan strategi pilihan, serta melakukan evaluasi. Sedangkan Arends dalam Ngalimun (2014) mengemukakan ada 5 fase (tahap) yang perlu dilakukan untuk mengimplementasikan PBL, yaitu :

1) Mengorientasikan siswa pada masalah

2) Mengorganisasikan siswa untuk belajar

3) Membimbing penyelidikan individu atau kelompok 
4) Mengembangkan dan menyajikan hasil karya, dan

5) Menganalisis dan mengevaluasi proses pemecahan masalah.

Dari pendapat di atas dapat disimpulkan bahwa untuk melaksanakan PBL dilakukan langkah-langkah sebagai berikut :

1) Orientasi siswa pada masalah

2) Mendiagnosis masalah

3) Melaksanakan penyelidikan individu atau kelompok

4) Mengembangkan dan menyajikan hasil pemecahan masalah

5) Evaluasi

Kelebihan penggunaan model pembelajaran berbasis masalah atau PBL dalam pembelajaran menurut Ngalimun (2014) antara lain :

1) Dengan PBL akan terjadi pembelajaran bermakna

2) Dalam PBL siswa mengintegrasikan pengetahuan dan ketrampilan secara simultan

3) PBL dapat meningkatkan kemampuan berpikir kritis, menumbuhkan inisiatif siswa dalam bekerja, motivasi internal, dan mengembangkan hubungan personal dalam kelompok.

Kelemahan model PBL antara lain:

1) Sulit bagi guru untuk mengubah gaya mengajar mereka.

2) Perlu lebih banyak waktu bagi siswa untuk memecahkan suatu masalah pada saat dipresentasikan/digunakan pertama kali di kelas.

3) Sulit menerapkan model PBL masalah di semua kelas.

Beberapa penelitian menunjukkan bahwa model PBL dapat meningkatkan hasil belajar siswa termasuk kemampuan pemecahan masalah. Salah satunya adalah penelitian yang dilakukan oleh Karatas dan Baki (2013) yang menyatakan bahwa siswa yang menerima pembelajaran berbasis pemecahan masalah sukses menyelesaikan soal-soal pemecahan masalah yang diberikan. Penelitian Padmavathy dan Mareesh (2013) mengenai efektivitas model PBL dalam pembelajaran matematika juga menunjukkan bahwa PBL dapat meningkatkan pengetahuan siswa, serta kemampuan untuk menggunakan konsep matematika dalam permasalahan seharihari

Dari kajian teori di atas, untuk mengatasi permasalahan masih rendahnya kemampuan pemecahan masalah matematika siswa khususnya materi lingkaran akan diterapkan model Problem Based Learning (PBL) dengan langkah-langkah seperti digambarkan dalam kerangka berpikir sebagai berikut :

\begin{tabular}{|c|c|c|}
\hline $\begin{array}{l}\text { Kondisi awal : } \\
\text { - Siswa kurang } \\
\text { terbiasa soal } \\
\text { pemecahan } \\
\text { masalah } \\
\text { - Kemampuan } \\
\text { pemecahan } \\
\text { masalah rendah } \\
\text { - Hasil belajar } \\
\text { rendah } \\
\text { - Belum } \\
\text { menggunakan } \\
\text { model PBL }\end{array}$ & $\begin{array}{l}\text { Tindakan : } \\
\text { Penerapan } \\
\text { model } \\
\text { Problem } \\
\text { Based } \\
\text { Learning } \\
\text { (PBL) }\end{array}$ & $\begin{array}{l}\text { Kondisi Akhir : } \\
\text { - Pembelajaran } \\
\text { dengan model } \\
\text { PBL terlaksana } \\
\text { dengan baik } \\
\text { - Kemampuan } \\
\text { pemecahan } \\
\text { masalah } \\
\text { matematika } \\
\text { siswa meningkat } \\
\text { - Hasil belajar } \\
\text { meningkat }\end{array}$ \\
\hline
\end{tabular}

Berdasarkan kajian teori di atas, hipotesis tindakan dalam penelitian ini adalah : Penerapan model PBL pada materi lingkaran dapat meningkatkan kemampuan pemecahan masalah matematika siswa.

\section{METODE PENELITIAN}

\section{Setting Penelitian}

Penelitian ini dilaksanakan di SMP Negeri 1 Masaran Kabupaten Sragen, di 
kelas VIII F Semester Genap Tahun pelajaran 2016/2017 selama 3 bulan, yaitu mulai bulan Januari 2017 sampai dengan bulan Maret 2017. Masa persiapan dilaksanakan mulai awal bulan Januari, pelaksanaan siklus I dimulai pada minggu keempat bulan Januari sampai minggu kedua bulan Februari, kemudian dilanjutkan siklus II mulai akhir Februari sampai minggu kedua bulan Maret 2017.

\section{Subjek Penelitian}

Subjek penelitian tindakan kelas ini adalah siswa kelas VIII F Semester Genap SMP Negeri 1 Masaran tahun pelajaran 2016/2017 yang berjumlah 31 siswa terdiri dari 12 siswa putra dan 19 siswa putri dengan kemampuan bervariasi.

\section{Teknik dan Alat Pengumpulan Data}

Data yang dikumpulkan dalam penelitian ini adalah data kegiatan guru dan siswa dalam pelaksanaan KBM dengan model PBL, data kemampuan pemecahan masalah matematika, dan data hasil belajar matematika. Data penerapan model PBL dalam pembelajaran adalah data mengenai kegiatan guru dan siswa dalam melaksanakan pembelajaran dengan model PBL. Data ini dikumpulkan melalui pengamatan. Kegiatan guru yang diamati meliputi kegiatan pendahuluan, inti, penutup, serta pengelolaan kelas. Sedang kegiatan siswa meliputi perhatian dan aktivitas siswa dalam KBM. Data peningkatan kemampuan pemecahan masalah matematika adalah data yang diperoleh dari hasil evaluasi/ tes dengan soal-soal pemecahan masalah. Data peningkatan hasil belajar diperoleh dari hasil evaluasi/ tes dengan soal pemahaman konsep.
Instrumen yang digunakan untuk mengumpulkan data adalah:

1. Lembar pengamatan: digunakan untuk mengetahui kegiatan guru dan aktivitas siswa dalam KBM dengan model PBL di kelas VIII F.

2. Lembar Evaluasi/ tes: digunakan untuk mengetahui hasil belajar matematika yang meliputi aspek pemahaman konsep maupun kemampuan pemecahan masalah.

a. Untuk aspek pemahaman konsep, akan ditentukan nilai rata-rata atau daya serap siswa, ketuntasan belajar, nilai tertinggi,dan nilai terendah.

b. Untuk aspek kemampuan pemecahan masalah akan ditentukan:

1). Kemampuan memahami soal dan merencanakan strategi penyelesaian.

2). Kemampuan menyelesaikan soal (melaksanakan strategi penyelesaian masalah).

3).Menjawab soal yang ditanyakan (mengecek hasil penyelesaian masalah)

3. Catatan lapangan dibuat guru peneliti untuk mencatat hal-hal yang terjadi selama kegiatan belajar mengajar berlangsung.

\section{Analisis Data}

Data yang diperoleh dari hasil pengamatan maupun hasil evaluasi/tes dianalisis secara deskriptif komparatif artinya hasil pengamatan aktivitas guru maupun siswa dan hasil belajar (pemahaman konsep maupun kemampuan pemecahan masalah) diungkapkan dengan prosentase, kemudian dibandingkan antara kondisi 
awal, hasil akhir siklus I, dan hasil akhir siklus II.

\section{Indikator Keberhasilan}

Penelitian ini dikatakan ada kemajuan atau keberhasilan apabila terjadi peningkatan kemampuan pemecahan masalah dan peningkatan hasil belajar siswa dari kondisi awal ke siklus I dan dari siklus I ke siklus II. Selama ini, sebelum penggunaan model PBL, kemampuan pemecahan masalah matematika masih rendah, hanya sekitar 50\%. Sedangkan hasil belajar siswa juga belum memuaskan, rata-rata ketuntasan siswa kurang dari $75 \%$ (hanya $62 \%$ ). Sehingga penelitian ini dikatakan berhasil jika:

1. Kemampuan pemecahan masalah matematika siswa lebih dari $60 \%$.

2. Ketuntasan belajar siswa mencapai lebih dari atau sama dengan $85 \%$ atau minimal $85 \%$ siswa telah memenuhi KKM 75.

\section{Prosedur Penelitian}

Rancangan tindakan yang akan dilaksanakan dituangkan dalam bentuk siklus yang terdiri dari perencanaan, pelaksanaan, pengamatan dan refleksi. Dalam penelitian ini akan dilaksanakan dua siklus.

\section{HASIL DAN PEMBAHASAN}

Penelitian tindakan kelas yang dilaksanakan oleh peneliti bersama kolaborator ini bertujuan untuk melihat gambaran peningkatan kemampuan pemecahan masalah matematika siswa serta hasil belajar matematika dengan penerapan model Problem Based Learning (PBL) untuk materi lingkaran pada siswa kelas VIII F Semester Genap
SMP Negeri 1 Masaran tahun pelajaran 2016/2017. Dari hasil ulangan harian untuk materi sebelumnya, yaitu materi SPLDV aspek pemahaman konsep, diperoleh nilai terendah 23 , nilai tertinggi 100 , nilai rata-rata siswa adalah 70,00 atau $70.00 \%$ untuk KKM 75. Sedang banyaknya siswa yang tuntas adalah 15 orang atau $48,39 \%$.

Setelah menerapkan model PBL, diperoleh hasil-hasil penelitian sebagai berikut:

\section{Penerapan Model PBL di SMPN 1 Masaran}

Pada awal siklus I, guru masih terkesan canggung dan kurang percaya diri dalam mulai menerapkan model PBL untuk materi keliling dan luas lingkaran. Siswa juga masih terlihat kebingungan dalam melaksanakan kegiatan. Langkahlangkah PBL juga masih dirasa sulit bagi sebagian siswa, sehingga guru harus berkali-kali menyampaikan apa yang harus dilakukan siswa. Pada siklus I ini penerapan pembelajaran dengan model PBL lebih banyak didominasi guru, artinya setiap langkah dari 5 langkah PBL harus dijelaskan guru secara terperinci, baru siswa melaksanakan kegiatan pembelajaran. Berasarkan pengamatan, pada pertemuan ke-1 Siklus I, penguasaan guru terhadap model PBL hanya $52,50 \%$ meningkat menjadi $60 \%$ pada akhir Siklus I.

Pada awal siklus II, penguasaan guru terhadap model PBL sudah sukup baik. Guru semakin percaya diri menggunakan model PBL. Berdasarkan pengamatan, penguasaan guru dalam menerapkan model PBL untuk materi hubungan antara sudut pusat, panjang busur, dan luas juring meningkat dari $82,50 \%$ pada awal 
siklus II menjadi 90,00\% pada akhir siklus II. Dengan demikian dapat dikatakan bahwa suatu model pembelajaran baru, jika dilaksanakan berulang maka akan menjadi terbiasa dan hasilnya akan meningkat.

Aktivitas siswa pada awal penerapan model PBL masih sangat rendah, yaitu kurang dari $50 \%$. Sebagian besar siswa menyatakan belum paham dengan model PBL terutama pada langkah-langkahnya. Pada saat orientasi dan mendiagnosa masalah kelihatan kalau kebanyakan siswa mengalami kebingungan. Pada tahap penyelidikan individu atau kelompok untuk menyelesaikan masalah atau menemukan konsep, dimana siswa harus mampu membuat kesimpulan yang benar, masih banyak kelompok yang mengalami kesulitan. Saat menuliskan rumus sebagai hasil kesimpulan dari kegiatan menyajikan hasil karya, juga masih ada kelompok yang masih menemui kendala. Setelah diselidiki penyebabnya adalah karena materi prasyarat kurang dikuasai oleh siswa. Dari hasil pengamatan, diketahui rata-rata aktivitas siswa $56,45 \%$ pada awal siklus I meningkat menjadi $62,90 \%$ pada akhir siklus I.

Pada awal siklus II, motivasi siswa untuk aktif dalam kegiatan pembelajaran semakin meningkat karena mereka lebih menyadari kegunaan dari menyelesaikan masalah untuk menemukan rumus atau konsep tertentu. Selain itu kerjasama dalam kelompok membuat persaingan antar kelompok untuk menjadi yang terbaik mulai kelihatan. Siswa yang biasanya diam dan pasif, karena pengaruh teman dalam kelompok, terlihat mulai ikut aktif berpartisipasi dalam kegiatan kelompok. Dari hasil pengamatan, diketahui rata-rata aktivitas siswa meningkat dari $77,41 \%$ pada awal siklus II meningkat menjadi $88,70 \%$ pada akhir siklus II.

Hasil pengamatan kegiatan guru dan aktivitas siswa dalam penerapan model PBL dapat dilihat pada Tabel I berikut.

Tabel 1.

Hasil Pengamatan Kegiatan Guru dan Siswa

\begin{tabular}{lcccc}
\hline \multicolumn{1}{r}{ Aspek yang diamati } & Jumlah Skor / Banyaknya & \multicolumn{2}{c}{ Prosentase } \\
\hline & Siklus I & Siklus II & Siklus I & Siklus II \\
\hline Kegiatan guru & & & 60,00 & 90,00 \\
\hline Aktivitas siswa & & & & \\
\hline a. Antusias/Perhatian & 17 & 26 & 54,83 & 83,87 \\
\hline b. Aktif & 22 & 29 & 79,96 & 93,54 \\
\hline Rata-rata & 19,5 & 27,5 & 62,90 & 88,70 \\
\hline
\end{tabular}

Dari tabel I di atas, diketahui bahwa model PBL dapat diterapkan dengan baik jika terdapat kerjasama yang baik antara guru dan siswa. Artinya guru mampu menggunakan dan menguasai langkah- langkah model PBL, sedangkan siswa mempunyai motivasi yang cukup untuk terlibat aktif dalam kegiatan pembelajaran. 


\section{Peningkatan Kemampuan Pemecahan Masalah Matematika Melalui Model PBL}

Tujuan penerapan model PBL pada penelitian ini adalah peningkatan hasil belajar siswa yang meliputi hasil belajar untuk aspek kemampuan pemecahan masalah dan hasil belajar aspek pemahaman konsep. Untuk aspek kemampuan pemecahan masalah, sesuai dengan indikator yang ditetapkan, rata- rata kemampuan pemecahan masalah meningkat dari 55,64\% pada siklus I meningkat menjadi $63,16 \%$ pada siklus II. Hal ini menunjukkan bahwa penerapan model PBL untuk materi lingkaran di kelas VIII F SMPN 1 Masaran dapat meningkatkan kemampuan pemecahan masalah matematika siswa. Hasil peningkatan ini dapat dilihat pada Tabel II berikut.

Tabel 1 I.

Hasil Evaluasi Kemampuan Pemecahan Masalah

\begin{tabular}{lcccc}
\hline \multicolumn{1}{c}{ Aspek yang diamati } & \multicolumn{2}{c}{ Jumlah Skor / Banyaknya } & \multicolumn{2}{c}{ Prosentase } \\
\hline & Siklus I & Siklus II & Siklus I & Siklus II \\
\hline kemampuan pemecahan masalah: & & & & \\
\hline 1) memahami soal & 173 & 207 & 69,75 & 83,46 \\
\hline 2) menyelesaikan soal & 149 & 159 & 60,08 & 64,11 \\
\hline 3) menjawab soal yang ditanyakan & 46 & 52 & 37,09 & 41,93 \\
\hline $\begin{array}{l}\text { Rata-rata kemampuan pemecahan } \\
\text { masalah }\end{array}$ & & & 55,64 & 63,16 \\
\hline
\end{tabular}

\section{Peningkatan Hasil Belajar Matematika melalui Model PBL}

Peningkatan hasil belajar siswa melalui penerapan model PBL pada penelitian ini dilihat dari hasil ulangan harian pada akhir siklus I untuk materi keliling dan luas lingkaran dan hasil ulangan harian pada akhir siklus II untuk materi hubungan sudut pusat, panjang busur, dan luas juring. Berdasarkan hasil penelitian diperoleh bahwa nilai rata-rata siswa mengalami peningkatan dari $73,76 \%$ pada akhir siklus I menjadi $84,62 \%$ pada akhir siklus II. Sedangkan ketuntasan belajar meningkat dari $64,52 \%$ menjadi $87,10 \%$. Rinsian hasil belajar dapat dilihat pada Tabel III berikut.

Tabel 1II.

Hasil Belajar/ Hasil Evaluasi Pemahaman Konsep

\begin{tabular}{lcccc}
\hline \multicolumn{1}{c}{ Aspek yang diamati } & \multicolumn{2}{c}{ Jumlah Skor / Banyaknya } & \multicolumn{2}{c}{ Prosentase } \\
\hline & Siklus I & Siklus II & Siklus I & Siklus II \\
\hline Pemahaman konsep & & & & \\
\hline 1) Rata-rata & 73,76 & 84,62 & 73,76 & 84,62 \\
\hline 2) Nilai terendah & 23 & 50 & & \\
\hline 3) Nilai tertinggi & 100 & 100 & & \\
\hline 4) ketuntasan & 20 & 27 & 64,52 & 87,10 \\
\hline
\end{tabular}

Dengan pembelajaran model PBL motivasi siswa untuk aktif dalam kegiatan pembelajaran dan mengembangkan kemampuan pemecahan 
masalah semakin meningkat karena siswa dibiasakan untuk mengetahui soal-soal bertipe pemecahan masalah dan dibiasakan memecahkan suatu masalah. Dari sini dapat diketahui bahwa kemampuan pemecahan masalah matematika dapat dibiasakan dengan memberikan soal-soal yang menuntut kemampuan siswa dalam memecahkan masalah matematika.

Hasil belajar siswa baik aspek pemahaman konsep maupun pemecahan masalah setelah mengikuti pembelajaran dengan model PBL semakin meningkat. Terbukti dengan terjadinya peningkatan prosentase masing-masing indikator kemampuan pemecahan masalah maupun indikator hasil belajar.

Hasil akhir dari penelitian ini yang meliputi penguasaan guru, aktivitas siswa, hasil belajar siswa baik aspek pemahaman konsep maupun kemampuan pemecahan masalah dapat dilihat pada Tabel IV sebagai berikut.

Tabel IV.

Aktivitas dan hasil belajar siswa pada siklus I dan siklus II

\begin{tabular}{lccc}
\hline & $\begin{array}{c}\text { Sebelum Tindakan } \\
(\%)\end{array}$ & $\begin{array}{c}\text { Siklus I } \\
(\%)\end{array}$ & $\begin{array}{c}\text { Siklus II } \\
(\%)\end{array}$ \\
\hline Aktivitas siswa & 58,06 & 59,67 & 88,70 \\
\hline $\begin{array}{l}\text { Hasil belajar pemahaman } \\
\text { konsep: }\end{array}$ & & & \\
\hline a. Daya serap & 70,00 & 73,76 & 84,62 \\
\hline $\begin{array}{l}\text { b. Ketuntasan belajar } \\
\text { Kemampuan pemecahan } \\
\text { masalah }\end{array}$ & 48,39 & 64,53 & 87,10 \\
\hline
\end{tabular}

Dari tabel di atas, dapat dilihat bahwa penerapan model PBL pada mata pelajaran matematika untuk materi lingkaran dapat meningkatkan aktivitas, hasil belajar pemahaman konsep, maupun kemampuan pemecahan masalah matematika. Dengan demikian kegiatan pembelajaran harus diusahakan agar siswa belajar pemahaman konsep, penalaran, maupun pemecahan masalah sebagai bekal siswa dalam menghadapi permasalahan matematika maupun permasalahan sehari-hari.

\section{SIMPULAN}

Penelitian yang dilaksanakan selama 2 siklus ini memberikan kesimpulan sebagai berikut :

Penerapan model pembelajaran PBL di kelas VIII F SMP Negeri 1 Masaran untuk materi lingkaran dapat meningkatkan hasil belajar yang berupa pemahaman konsep maupun kemampuan pemecahan masalah jika guru menguasai dan dapat menggunakan model PBL dengan baik. Penerapan model PBL dilakukan dengan langkah-langkah: orientasi siswa pada masalah, mendiagnosis masalah, melaksanakan penyelidikan individu atau kelompok, mengembangkan dan menyajikan hasil pemecahan masalah, serta melakukan evaluasi.

Penerapan model PBL dalam pembelajaran matematika dapat meningkatkan aktivitas belajar siswa sebesar $25,80 \%$ dari $62,90 \%$ pada siklus I menjadi $88,707 \%$ pada akhir siklus II. Penerapan model PBL dapat 
meningkatkan kemampuan pemecahan masalah matematika siswa sebesar 7,52\% dari 55,64\% pada akhir siklus I menjadi $63,16 \%$ pada akhir siklus II. Peningkatan ini dapat dilihat dari indikator: kemampuan memahami soal dan merencanakan strategi penyelesaian naik dari $69,75 \%$ menjadi $83,46 \%$, kemampuan menyelesaikan soal naik dari $60,08 \%$ menjadi $64,11 \%$, dan menjawab soal yang ditanyakan (mengecek hasil penyelesaian masalah) naik dari $37,09 \%$ menjadi $41,93 \%$.

Penerapan model PBL dapat meningkatkan hasil belajar siswa dengan indikator: nilai rata-rata ulangan harian siswa meningkat $10,86 \%$ dari $73,76 \%$ pada akhir siklus I menjadi $84,62 \%$ pada akhir siklus II, sedangkan ketuntasan belajar siswa meningkat sebesar $22,58 \%$ dari $64,52 \%$ pada akhir siklus I menjadi $87,10 \%$ pada akhir siklus II.

\section{DAFTAR PUSTAKA}

Akinmola, E.A. (2014). Developing Mathematical Problem Solving Ability: A Panacea For Sustainable Development in The $21^{\mathrm{ST}}$ Century. International Journal of Education and Research. Volume 2, No. 2, pp. 2-12.

Dimyati \& Mudjiono. (2009). Belajar dan Pembelajaran. Jakarta: Rineka Cipta.

Karatas, I. \& Baki, A. (2013). The Effect of Learning Environments Based on Problem Solving on Students' Achievements of Problem Solving. International Electronic Journal of Elementary Education. Volume 5, No. 3, pp. 249-268.

Kemdikbud. (2014). Permendikbud Nomor 58 Tahun 2014 Tentang Kurikulum 2013. Jakarta: Kemdikbud.

Kemdikbud. (2015). Buku Guru Matematika SMP/MTs Kelas IX. Jakarta: Kemdikbud.

Mulyono Abdurrahman. (2003). Pendidikan Bagi Anak Berkesulitan Belajar. Jakarta: Rineka Cipta.

Nana Sudjana. (2010). Penilaian Hasil Belajar. Bandung : Remaja Rosda Karya.

Ngalimun. (2014). Strategi dan Model Pembelajaran. Yogyakarta: Aswaja Pressindo.

Padmavathy, R.D. \& Mareesh, K. (2013). Effectiveness of Problem Based Learning in Mathematics. International Multidisciplinary e-Journal. Volume II, Issue-I, pp. 4551.

Wina Sanjaya. (2006). Strategi Pembelajaran Berorientasi Standar Proses. Jakarta: Kencana. 
JURNAL LITBANG SUKOWATI | VOLUME 2 | NOMOR 2 | TAHUN 2019 | HAL. 48 - 59 